\title{
PENERAPAN PENDIDIKAN DAN PELATIHAN \\ BERBASISKAN EMOTIONAL SPIRITUAL \\ QUOTIENT (ESQ) PADA BALAI DIKLAT \\ KEAGAMAAN MANADO
}

\author{
Muhammad Anwar
}

Balai Diklat Keagamaan Manado

\begin{abstract}
Abstrak
Pendidikan dan pelatihan yang dilaksanakan selama ini lebih berorientasi pada pemenuhan kompetensi pada aspek kognitif. Pada kenyataannya, aspek kognitif saja dinilai tidak cukup karena tujuan pendidikan dan pelatihan juga mesti berorientasi pada pemenuhan aspek emotional spiritual quotient (ESQ). Dan hal ini harus terintegrasi pada semua materi/mata diklat termasuk mata pelajaran sains. Misalnya, penanaman motivasi untuk melestarikan bumi atau hikmah penciptaan semesta melalui pelajaran biologi.

Dengan demikian, pemilihan peserta diklat teladan yang selama ini lebih banyak mendasarkan pada penilaian cognitive - based competition semata, sudah saatnya paradigma itu ditinjau kembali. Peserta diklat teladan bukan saja peserta yang berprestasi dalam hal "ranking kelas", akan tetapi peserta diklat yang berkarakter mandiri, takwa, peka sosial, seharusnya mendapat apresiasi dan penilaian lebih. Lingkungan yang sehat bukan saja memberikan stimulasi positif sebagai proses transfer pengetahuan, tetapi juga memudahkan optimalisasi nilai-nilai luhur dalam lingkup pendidikan. Lingkungan sehat dapat dibentuk melalui budaya yang sehat pula. Mengembalikan fungsi fasilitas ibadah di lingkup akademik. Misalnya, memberikan ruang ibadah kepada peserta diklat, baik peserta diklat yang beragama islam, kristen, katolik, budha, hindu, maupun konhuchu. Hal ini dimaksudkan agar mengerjakan sesuatu harus selalu mengingat kepada Tuhan, Sang Pencipta.
\end{abstract}


Oleh karena itu, untuk meningkatkan sumber daya manusia pada Kementrian Agama khususnya pada Balai Diklat Keagamaan Manado, maka diperlukan model pendidikan dan pelatihan yang berbasis ESQ. ESQ ini dapat di integrasikan pada kurikulum dan silabus pada program pendidikan dan pelatihan pada setiap penyelenggaraan diklat. Dengan adanya muatan kurikulum dan mata diklat yang terintegrasi pada Emotional Quotient (EQ) dan Spiritual Quotient (SQ), maka ke depan akan didapatkan sumber daya manusia yang siap pakai, baik secara IQ, EQ, maupun SQ.

\section{Kata Kunci : Pendidikan dan Pelatihan, Emosial Spiritual Question.}

\section{A. Pendahuluan}

Pendidikan dan pelatihan (diklat) merupakan suatu proses pembelajaran dalam pemenuhan kebutuhan suatu organisasi yang dikelola secara sistematis dan profesional guna mengarahkan pegawai pada perubahan kemampuan (kompetensi), sikap, dan perilaku untuk memenuhi tuntutan kualifikasi kerja dan dinamika perkembangan organisasi. Diklat sebagaimana dimaksud di lingkungan pemerintah termasuk pada Kementrian Agama mempunyai urgensi strategis dalam misi peningkatan kualitas pegawai (sumber daya manusia) sebagai bagian dari reformasi pemerintahan dalam rangka pencapaian good governance.

Upaya strategis menuju good governance salah satunya ditempuh melalui pembenahan kinerja, yang tidak hanya pada level staf saja, melainkan seluruh pegawai meliputi jajaran pimpinan sampai pegawai operasional sehingga terjadi pergerakan secara terarah dan simultan. Salah satu bentuknya adalah pengembangan pegawai yang dilakukan melalui kemasan diklat yang match dengan fungsinya, sehingga memberikan dampak positif terhadap kinerja organisasinya.

Upaya peningkatan sumber daya manusia (SDM) dalam bidang pendidikan dan pelatihan, tentunya ada yang harus dikembangkan setiap waktu sesuai perkembangan jaman dan tuntutan masyarakat luas terutama pada pengembangan SDM Kementrian Agama khususnya. Pengembangan tersebut difokuskan kepada pengetahuan (knowledge), sikap (attitude) dan keterampilan (skill) untuk 
menopang kemampuan (kompetensi) seluruh pegawai pada Kementrian Agama. Berdasarkan PPRI NO. 101 Tahun 2000 disebutkan bahwa tujuan diklat antara lain meningkatkan pengetahuan, keterampilan, dan sikap pegawai untuk dapat melakukan tugas secara profesional dengan dilandasi kepribadian dan etika PNS sesuai kebutuhan instansi, memantapkan sikap dan semangat pengabdian yang berorientasi pada pelayanan, pengayoman, dan pemberdayaan masyarakat, dan menciptakan kesamaan visi dan dinamika pola pikir.

Seiring dengan dinamika kehidupan dan perkembangan organisasi kediklatan yang semakin kompetitif, maka kondisi lingkungan, baik internal maupun eksternal juga akan terus mengalami perubahan dan penyesuaian. Banyak cara yang dapat di lakukan untuk mengantisipasi dan merespon perubahan tersebut, dan strategi pertama untuk mulai melakukan perubahan antara lain dengan melakukan hal-hal yaitu: a) pengendalian diri secara lebih baik dengan di sertai kearifan, b) beradaptasi dengan perbahan yang terjadi sambil mengubah paradigma berfikir dan bertindak, c) komunikasi yang efektif untuk membangun kepercayaan dan mengembangkan networking, d) penyelarasan dan/atau menyeimbangkan antara kematangan Intelectual Quotion (IQ) Emotional Quotion (EQ) dan Spiritual Quotion (SQ).

Kebutuhan terhadap diklat muncul karena sejumlah permasalahan yang di identifikasi dapat menjadi kendala kinerja organisasi, seperti menurunnya prestasi kerja, sikap pengabdian yang menipis, dan terjadinya tantangan perubahan lingkugan strategis. Tulisan ini berfokus pada pendidikan dan pelatihan berbasiskan Emotional Spiritual Quotion (ESQ) pada yang dapat di kembangkan pada Balai Diklat Keagamaan Manado. Oleh karena itu, kajiannya di arahkan pada dua aspek, yaitu : 1) Bagaimana kurikulum pendidikan dan pelatihan berbasiskan ESQ pada Balai Diklat Keagamaan Manado? Dan 2) Bagaimana optimalisasi ESQ dalam pendidikan dan pelatihan pada Balai Diklat Keagamaan Manado?

\section{B. Pembahasan \\ 1. Teori Kurikulum \\ a. Konsep kurikulum}


Kurikulum adalah suatu perangkat pernyataan yang memberikan makna terhadap kurikulum lembaga. Makana tersebut terjadi karena adanya penegasan hubungan antara unsur-unsur kurikulum, karena adanya petunjuk perkembangan, penggunaan, dan evaluasi kurikulum. Konsep terpenting yang perlu mendapatkan penjelasan dlam teori kurikulum adalah konsep kurikulum. Menurut Mohammad Ali, dkk (2007), ada tiga konsep tentang kurikulum, yaitu kurikulum sebagai substansi, sebagai sistem, dan sebagai bidang studi/ mata diklat.

Konsep pertama ialah kurikulum sebagai suatu substansi, yaitu suatu kurikulum di pandang sebagai suatu rencana belajar bagi murid/ siswa/ mahasiswa/ peserta diklat di lembaga pendidikan, yang menjadi suatu perangkat tujuan yang ingin di capai. Suatu kurikulum juga dapat menunjuk kepada suatu dokumen yang berisi rumusan tentang tujuan, bahan ajar, kegiatan belajar mengajar, jadwal dan evaluasi. Selain itu, kurikulum juga dapat di gambarkan sebagai suatu dokumen tertulis sebagai hasil persetujuan bersama antara para penyusun kurikulum dan pemegang kebijaksanaan pendidikan dengan masyarakat.

Konsep kedua adalah kurikulum sebagai sistem, yaitu sistim kurikulum. Sistim kurikulum merupakan bagian sistim diklat, sistim pendidikan itu sendiri, bahkan sistim masyarakat. Suatu sistim kurikulum mencakup sistim struktur personalia, dan prosedur kerja bagaimana cara menyusun kurikulum, melaksanakan, mengevaluasi, dan menyempurnakan. Hasil dari suatu sistim kurikulum adalah tersusunnya suatu kurikulum, dan fungsi dan sistim kurikulum adalah sebagaimana memelihara kurikulum agar tetap dinamis.

Konsep ketiga ialah kurikulum sebagai sebagai suatu bidang studi/ mata diklat yaitu mata pelajaran kurikulum. Ini merupakan bidang kajian para ahli kurikulum dan ahli pendidikan dan pengajaran. Tujuan kurikulum sebagai bidang studi adalah mengembangkan ilmu tentang kurikulum dan sistim kurikulum.

Di dalam penyelenggaraan pendidikan dan pelatihan, perlunya perubahan kurikulum dengan perubahan kurikulum substansi yang merupakan rumusan tujuan, bahan ajar, proses belajar mengajar dan evaluasi kediklatan. Hal ini dilakukan untuk meningkatkan kinerja sumber daya manusia yang berakhlak 
mulia yang berdasarkan kemampuan IQ,EQ dan SQ pada lembaga pendidikan dan pelatihan. Kurikulum bersesuaian dengan sistim, oleh karena itu kurikulum sebagai sistim ini adalah yang di dalamnya terdapat SDM yang berinteraksi sesuai dengan karakter masing-masing yang menjunjung tinggi nilai-nilai ketuhanan, dan norma-norma atau budaya kebangsaan sebagai bangsa beragama. Kurikulum sebagai suatu bidang studi, tentu sangat penting karena dengan bidang studi/ mata diklat yang akan di sajikan pada setiap peserta diklat/ mahasiswa/ siswa harus di dasarkan pada nilai-nilai yang terkandung pada dasar negarakita yaitu Pancasila dan UUD 1945.

Salah satu kegiatan utama penyelenggaraan diklat adalah mendesain programnya. Desain adalah proses perencanaan yang menggambarkan urutan kegiatan (sistematika) mengenai suatu program. Desain program diklat adalah proses perencanaan urutan kegiatan komponen diklat yang merupakan suatu kesatuan bulat dari program tersebut. Ada tiga unsur penting dalam setiap desain diklat yang perlu di perhatikan dalam upaya meningkatkan kegiatan bagi setiap individu, yaitu: 1) maksud (apa yang harus dicapai); 2) metode ( bagaimana mencapai tujuan); 3) format ( dalam keadaan bagaimana penentuan rancan bangun yang ada ingin di capai) (Admodiwiro, 2002:56)

Adapun tujuan rancang bangunn program diklat adalah 1) mengetahui secara sistematis tahapan kegiatan diklat; 2) mengetahui aspek-aspek dan fokus diklat; 3) mengetahui model diklat yang di gunakan; 4) menyiapkan bahan yang di gunakan. Manfaat rancang bangun adalah: 1) merupakan pedoman/ acuan dalam pelaksanaan diklat; 2) menyiapkan bahan-bahan, metode yang di gunakan model rancang bangun dalam penyelenggaraan pendidikan dan pelatihan.

\section{b. Konsep perubahan kurikulum}

Pada hakikatnya kehidupan manusia maupun organisasi di liputi oleh perubahan dan inovasi secara berkelanjutan. Di karenakan adanya faktor eksternal yang mendorong terjadinya perubahan demi untuk eningkatkan penyelenggaraan dan output suatu pelaksanaan kediklatan. Perubahan kurikulum secara substansi atau pengembangan kurikulum merupakan juga suatu perubahan atau inovasi secara berkelanjutan di laksanakan. 
Menurut Tom Peter (1999) The only constant thing today is change, satusatunya hal yang tetap saat ini adalah perubahan. Sehingga dalam setiap orang, organisasi jika ingin menjemput masa depan yang carah maka harus dilakukan perubahan, baik perubahan secara internal maupun perubahan eksternal.

Dengan demikian, perubahan kurikulum adalah salah satu cara untuk melakukan inovasi pada lembaga pendidikan dan pelatihan (diklat), dalam rangka peningkatan sumber daya manusia baik dari segi pembelajaran, proses belajar mengajar serta pembentukan sikap sebagai insan beriman dan bertakwa. Dengan demikian, inovasi kurikulum berarti mengadakan pembaharuan pada sistim kediklatan yang sudah berlangsung lama.

Kennedy (1987: 163) juga membicarakan strategi inovasi yang di kutip dari Chin dan Benne (1970) yang menyarankan tiga jenis strategi inovasi, yaitu Power Coercive (strategi pemaksaan), Rational Emperical (empirik rasional), dan Normative-Re-Educative ( pendidikan yang berulang secara normatif)

Strategi inovasi yang pertama adalah strategi pemaksaan berdasarkan kekuasaan merupakan suatu pola inovasi yang sangat bertentangan dengan kaidah-kaidah inovasi itu sendiri. Strategi ini cenderung memaksakan kehendak, ide dan pikiran sepihak tanpa menghiraukan kondisi dan keadaan serta situasi yang sebenarnya dimana inovasi itu akan dilaksanakan. Kekuasaan memegang peranan yang sangat kuat pengaruhnya dalam menerapkan ide-ide baru dan perubahan yang sesuai dengan kehendak dan pikiran-pikiran dari pencipta inovasinya. Pihak pelaksana yang sebenarnya merupakan objek utama dari inovasi itu sendiri sama sekali tidak melibatkan baik dalam proses perencanaan maupun pelaksanaannya. Para inovator hanya menganggap pelaksana sebgai obyek semata dan bukan sebagai subyek yang juga harus diperhatikan dan dilibatkan secara aktif dalam proses perencanaan dan pengimplementasiannya.

Strategi inovasi yang kedua adalah empirik rasional. Asumsi dasar dalam strategi ini adalah bahwa manusia mampu menggunakan pikiran logisnya atau akalnya sehingga mereka akan bertindak secara rasional. Dalam kaitan dengan ini, 
inovator bertugas mendemontrasikan inovasinya dengan menggunakan metode yang terbaik dan valid unutk memberikan manfaat bagi penggunanya. Disamping itu strategi ini didasarkan atas pandangan yang optimistik (Bennis, Benne, dan Chin dalam Wijaya,dkk 1991).

Berdasarkan dua strategi inovasi di atas, maka kurikulum merupakan salah satu bentuk yang layak di jadikan sebagai pembaharuan suatu organisasi dengan melihat perubahan kurikulum organisasi tersebut. Hal ini sesuai dengan amanat Peraturan Menteri Agama (PMA) nomor 4 tahun 2012 tentang penyelenggaraan Diklat Teknis di Lingkungan Kementerian Agama RI.

\section{Teori kecerdasan (Quotien)}

\section{a. Intelligence Quotient (IQ)}

Pada awal tahun 1970-an, tidak sedikit ahli psikologi dunia yang berpendapat bahwa tes Intelligence Quotient (IQ) yang banyak di terapkan di dunia pendidikan itu tidak valid. Gardner menulis tentang konsep multiple intelligences yang memberikan kritikan yang mendalam tentang ketidak validan tes IQ. Kritikan ini berhasil memberikan kekuatan dan inspirasi bagi psikolog-psikolog dunia untuk mengintropeksi diri dan kembali merenungkan makna kecerdasan manusia.

Alferd Binet, pembuat tes IQ, adalah seorang psikolog yang profesional, tetapi tidak mampu menolak permintaan penguasa dan birokratis yang tidak profesional untuk menghubungkan kecerdasan seseorang dengan eugenic (faktor keturunan). Berhubungan dengan konsep tersebut bahwa seorang ysng memiliki IQ rendah dari orang tuanya, bagaimanapun usaha kita dalam meningkatkan IQ seseorang melalui diklat akan tetap tidak berkembang karena pengaruh gen (keturunan). Ini menyebabkan bahwa teori dari Binet tidak dapat dijadikan sebagai acuan untuk melaksanakan pengembang SDM yang maju.

Menrutu Valentine Dmitriev, ada dua faktor dalam perkembangan otak manusia yang menjadikan bebrapa orang lebih pandai dari pada orang lain. 
Faktor itu adalah keturunan dan lingkungan. Tidak banyak yang di lakukan oleh orang tua untuk menguba gen seorang bayi, tetapi sangat banyak yang bisa di lakukan untuk mengoptimalkan faktor lingkungan guna meningkatkan potensi perkembangan seorang anak. Lebih lanjut, Ridley (2003) mengemukakan bahwa gen bukanlah Blue Print statis hingga menjadi satusatunya penentu masa depan seseorang. Gen akan berkembang dan di pengaruhi oleh perubahan kondisi uterus (rahim), lingkungan dan beberapa faktor lain.

Dapat di jelaskan bahwa gen bukanlah satu-satunya menentukan masa depan anak, tetapi ada beberapa hal dapat mengembangkannya tergantung anak itu berada pada kondisi yang sesuai dengan bakat serta minat anak tersebut.

Sejauh yang dilakukan pada Balai Diklat Keagamaan Manado dari tahun 1990-2012 ini yaitu mengedepankan sistim kediklatan dengan lebih mempriotitaskan IQ dan bukan pada sikap dan mental peserta diklat, kendatipun dalam kurikulum yang di kembangkan, aspek kognitif, afektif dan psikomotorik di tuangkan secara jelas dalam dokumen kurkulum. Dalam prakteknya aspek IQ lebih di tonjolkan, yang seharusnya adalah baik aspek IQ, EQ, maupun SQ harus di kembangkan secara seimbang agar peserta diklat dapat mencapai kesuksesan dalam menjalankan tugas sebagai abdi negara yang baik dan berakhlak mulia. Keberhasilan yang di capai oleh Balai Diklat Keagamaan Manado dari segi intelektual, memang sangat di munkinkan, tetapi belum tentu dapat dilaksanakan dengan sebaik-baiknya. Hal ini terjadi karena tidak adanya sinkronisasi antara IQ,EQ dan SQ dari output penyelenggaraan kediklatan.

IQ adalah ukuran kemampuan intelektual, analisis, logika dan rasio seseorang. Dengan demikian, hal ini berkaitan dengan keterampilan berbicara, kesadaran akan ruang, kesadaran akan sesuatu yang tampak, dan penguasaan matematika. IQ mengukur kecepatan kita untuk mempelajari hal-hal baru memusatkan perhatian pada aneka tugas dan latihan, menyimpan dan mengikat 
kembali informasi objektif, terlibat dalam proses berfikir, bekerja dengan angka, berfikir abstrak dan analisis, serta memecahkan permasalahan dengan menerapkan pengetahuan yang telah ada sebelumnya. Jika IQ kita tinggi, angka rata-ratanya 100, kita memiliki modal yang sangat baik untuk lulus dari semua ujian dengan gemilang, dan (bukan kebetulan) meraih nilai yang baik dalam uji IQ.

Di dalam pendidikan dan pelatihan, ada tiga ranah yang di kembangkan yaitu pengetahuan (IQ), Sikap (EQ) dan psikomotorik. Dalam pedoman pembentukan sikap khususnya pada pelaksanaan kediklatan yang menjadi perhatian adalah ketiga ranah tersebut, namun kesemuanya selalu di fokuskan pada pengetahuan saja atau IQ saja, sehingga kecerdasan emosional, kecerdasan spiritual terabaikan. Ini semua mengakibatkan pendidikan pelatihan hanya membekali dari segi kemampuan intelektual saja bukan pada emosional dan spiritual.

\section{b. Emotional Intelligence/Quotient (EI/EQ)}

Istilah kecerdasan emosi baru dikenal secara luas pada pertengahan tahun 1990-an dengan diterbitkannya buku Daniel Goleman berjudul Emotional Intelegence. Sebenarnya Goleman telah melakukan riset IQ ini lebih dari 10 tahun. Ia menunggu waktu lama untuk mengumpulkan bukti ilmiah yang kuat. Sehingga saat goleman mempublikasikan penelitiannya, Emotional Intelegence, mendapat sambutan positif, baik dari akademisi, maupun praktisi.

Menurut Goleman (2002) bahwa kcerdasan emosi adalah kemampuan untuk menenali perasaan kita sendiri dan perasaan orang lain, kemampuan untuk memoifasi diri sendiri, dan kemampuan untuk mengelola emosi dengan baik pada diri sendiri dan dalam hubungannya dengan orang lain. Berdasarkan pendapat Goleman tersebut, pendidikan dan pelatihan dari setiap anggota diklat seharusnya berorientasi pada kemampuan untuk menguasai diri sendiri, memotiffasi untuk berbuat sesuatu yang baik dan dapat mengelola emosi untuk berhubungan dengan orang lain. Di dalam diklat yang diselenggarakan oleh setiap lembaga diklat lebih mengedepankan pada kognitif saja, bukan pada 
bagaimana seorang guru, pelajar, mahasiswa, dan masyarakat luas untuk memperkaya diri dari emosi yang terkontrol dan mampu megendalikan diri dari perbuatan yang tidak diinginkan. Kecerdasan emosional (Emotional Quotient) adalah kemampuan seseorang untuk menerima, menilai, mengelola, serta mengontrol emosi dirinya dan orang lain disekitarnya.

Menurut Goleman (2002),EQ menjadi unsur penting dari kepemimpinan. Berdasarkan penelitian ahli saraf dan ahli jiwa sekaitan dengan perkembangan otak yang kemudian disintesa oleh Goleman, disimpulkan bahwa kesuksesan dalam hal menyelesaikan pekerjaan, prosentase kebergantunggan kepada IQ hanya $20 \%$, selebihnya bergantung pada IQ. Dengan demikian EQ sangat tergantung pada pengalaman hidup sewaktu kecil, sekolah, perkembangan dilingkungan keluarga, peristiwa penting yang membekas kesan. EQ dapat dikembangan oleh diri sendiri. Eq dapat mempengaruhi adaptasi dalam bekerja, dapat mengatasi emosi dan cenderung bersifat optimistis, sehingga menimbulkan kompetensi personal dan kompetensi sosial.

Kecerdasan emosi mencakup kemampuan-kemampuan yang berbeda, tetapi saling melengkapi, dengan kecerdasan akademik (academic Intelegence) yaitu kemampuan-kemampuan kognitif murni yang diukur dengan IQ meskipun IQ tinggi, tetapi bila kecerdasan emosi rendah tidak akan banyak membantu banyak orang cerdas, dalam arti terpelajar, tetapi tidak mempunyai kecerdasan emosi, ternyata bekerja menjadi bawahan dari seseorang IQ nya lebih rendah, tetapi unggul dalam keterampilan dan kecerdasan emosi.

\section{c. Spiritual Quetien (SQ)}

Perlu dipahami bahwa SQ tidak meski berhubungan dengan agama, SQ adalah kecerdasan jiwa yang dapat membantu seseorang menbangun dirinya sendiri secara utuh. SQ tidak bergantung pada budaya atau nilai. Tidak mengikuti nilai-nilai yang ada, tetapi menciptakan kemungkinan untuk memiliki nilai-nilai itu sendiri. Kederdasan spritual adalah kecerdasan yang berasal dari dalam hati, menjadikan kita kreatif ketika kita dihadapkan pada 
masalah pribadi, dan mencoba melihat makna yang terkandung didalamnya, serta menyelesaikannya dengan baik agar memperoleh ketenangan dan kedamaian hati. Kederdasan spritual membuat indifidu mampu memaknai setiap kegiatannya sebagai ibadah, demi kepentingan umat manusia dan tuhan yang sangat dicintainya.

Penelitian yang melibatkan ratusan perusahaan dan eksekutif dalam bisnis, menunjukan pentingnya spirit. Salah satu faktor penentu sukses bisnis adalah kesadaran makna spirit. Yakni bahwa bisnis ini bermakna bagi diri, keluarga, negara, dan masa depan umat manusia. Sebaliknya, kekeringan makna spirit justru mengancam beberapa perusahaan, termasuk pada lembaga-lembaga perintah, baik birokrasi pemerintah maupun yang lainnya. Mereka sukses dari ukuran luar tetapi gersang dari dalam. Lebih jauh lagi, spirit justru menarik semua pihak untuk terus maju mencapai yang lebih sempurna.

Dimensi spiritual adalah komitmen individu pada sistim nilai yang di anut. Pembaharuan dan pengembangan spiritual memerlukan investasi waktu. Namun, sebenarnya tidak punya waktu untuk mengabaikan aktifitas pembaharuan. Tokoh pembaharuan besar, Marthin Luther, mengatakan, ada begitu banyak yang harus saya kerjakan hari ini, sehingga saya harus menyisikan waktu satu jam lagi untuk berdoa. (Nggermanto, 2002). Baginya, doa bukan merupakan tugas yang mekanis, melainkan lebih merupakan sumber kekuasaan dalam melepaskan dan melipatgandakan energinya.

Dalam catatan pribadi Stephen R. Covey, ia menulis bahwa ada bagian dari sifat manusia yang tidak dapat di capai melalui undang-undang, pendidikan, dan diklat, tetapi memerlukan kekuatan Tuhan untuk mengatasinya (Nggermanto 2002), Covey menyatakan bahwa manusia tidak dapat menyempurnakan diri kita sendiri. Sampai tingkat dimana kita menyelaraskan diri kita dengan prinsip yang benar, anugerah ilahi akan di serahkan pada sifat kita sehingga memungkinkan kita memenuhi ukuran ciptaan kita. Dalam kata- 
kata Teilhard de Chardin, kita bukan manusia yang memiliki pengalaman spiritual, kita adalah makhluk spiritual yang memiliki pengalaman manusia.

Menurut Zohar, kecerdasan spiritual (SQ) adalah kecerdasan yang bertumpuh pada bagian dalam diri kita yang berhubungan dengan kearifan di luar ego, atau jiwa sadar. Lanjut dari konsep ini, Sinetar mengemukakan kecerdasan spiritual adalah kecerdasan yang mendapat inspirasi,dorongan, dan efektivitas dan terinspirasi, theis-ness atau penghayatan ketuhanan yang di dalamnya kita semua menjadi bagian.

Muhammad Zuhri memberikan definisi yang menarik. IQ adalah kecerdasan manusia yang terutama digunakan manusia untuk berhubungan dengan mengelola alam. IQ setiap orang dipengaruhi oleh materi otaknya, yang ditentukan oleh faktor genetika. Meski demikian potensi IQ sangat besar. Sedangkan EQ adalah kecerdasan manusia yang terutama digunakan manusia untuk berhubungan dan bekerjasama dengan manusia lainnya. EQ seseorang dipengaruhi oleh kondisi dalam dirinya dan masyarakatnya, seperti adat dan tradisi. Potensi EQ manusia lebih besar dibanding IQ, sedangkan SQ adalah kecerdasan manusia yang digunakan untuk berhubungan dengan Tuhan. Potensi SQ adalah kecerdasan manusia yang digunakan untuk berhubungan dengan Tuhan. Potensi SQ setiap orang sangat besar, dan tidak dibatasi oleh faktor keturunan, lingkungan atau materi lainnya.

\section{d. Emotional Spiritual Quotient (ESQ)}

Selama ini banyak berkembang dalam masyarakat luas sebuah pandangan dengan mendikotomi antara kehidupan di dunia dan kehidupan di akhirat. Mengutip pemikiran Stephen R. Covey sebagaimana di sitir oleh Agustian (2001), tentang devinisi dasar dari efektifitas, dan hubungan kausalitas antara upaya dan hasil. Dengan melihat keunggulan EQ dalam mencapai prestasi, banyak orang hasil "penggodokan" pemikiran dan teori barat tersebut menjadi terkenal dan mencapai kesuksesan di atas rata-rata. 
Kecerdasan spiritual yang merupakan temuan terkini secara ilmiah, pertama kali digagas oleh Danah Zohar dan Ian Marshall, masing-masing dari Harvard University dan Oxford University memalui riset yang sangat komprehensif.

Pembuktian ilmiah tentang kecerdasan spritual yang dipaparkan Zohar dan Marshall dalam SQ, Spritual Quotient, The Ultimate Intelegence (london,2000), dua di antaranya adalah: pertama, riset ahli psikolog/syarat,Michael Persinger pada awal tahun 1990-an, lebih mutahir dari tahun 1997 oleh ahli syaraf V.S. Ramachandran dan timnya dari california University, yang menemukan eksistensi God-Spot dalam otak manusia.

Sedangkan, bukti kedua adalah riset ahli syaraf Austria, Wolf Singer pada era 1990-an atas The Building Problem, yang menunjukkan ada proses syaraf dalam otak manusia yang terkontrasi pada usaha yang mempersatu dan memberi makna dalam pengalaman hidup kita. Suatu jaringan syaraf yang secara literal 'hidup lebih bermakna'. Pada Got-spot inilah sebenarnya trdapat fitrah manusia yang terdalam.

Akan tetapi, SQ dari barat itu, atau sritual intelegence tersebut beln atau bahkan tidak menjangkau aspek ketuhanan. Kebenaran sejat, terletak paa suara hati yang bersumber dari spritual center ini, yang tidak bisa ditipu oleh siapapun, termasuk diri kita sendiri. Mata hati ini dapat mengungkap kebenaran hakiki yang tak tampak dihadapan mata. Bahkan kata ahli sufi Islam Jalaludin Rumi, "mata hati punya kemampuan 70 kali lebih besar untuk melihat kebenaran daripada dua indra penglihatan".

Dengan melihat kajian atas bahwa ternyata SQ sangat berperan penting dalam kehidupan sehari-hari, dengan membuka cakrawala berfikir dengan menggunakan IQ untuk memberikan suatu nuansa yang beriringan dengan pengembangan hubungan antara manusia dengan Tuhannya dan dapat digabungkan keduanya. Hubungan antara EQ dan SQ adalah untuk mencapai kesuksesan kehidupan dunia dan kehidupan di akhirat nanti. Oleh karena, Ary 
Ginanjar Agustian (2008) memberikan model penggabungan antara keduanya untuk mendapatkan energi untuk menyusun metode dalam menemukan pengetahuan yang benar dan hakiki. Hubungannya antara EQ dan SQ dapat dibuat suatu metode hubungan sebagai berikut:
1. EQ
II. Spritual
III. ESQ Tuhan

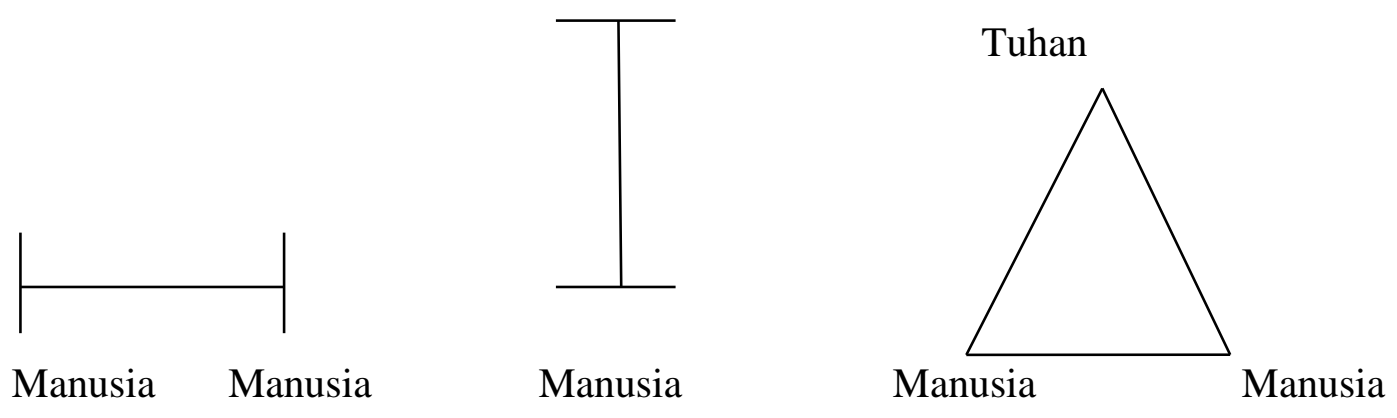

Dari beberapa hubungan di atas, maka juga dapat di gambarkan antara IQ, EQ, dan SQ dan Tuhan, untuk mencoba memberikan pemahaman, cara pemeliharaan, dan yang terpenting adalah metode pelatihan jangka panjang yang mandiri, tanpa unsur paksaan batiniah, dan dengan memanfaatan kekuatan - kekuatan ikiran bawah sadar atau yang lebih di kenal dengan suara hati yang terletak pada Goot Spot. Hubungan antara IQ, EQ dan SQ dan Tuhan sebagai model ESQ dapat di gambarkan sebagai berikut: 
Tuban

Spritual

'

SQ (God Spot)

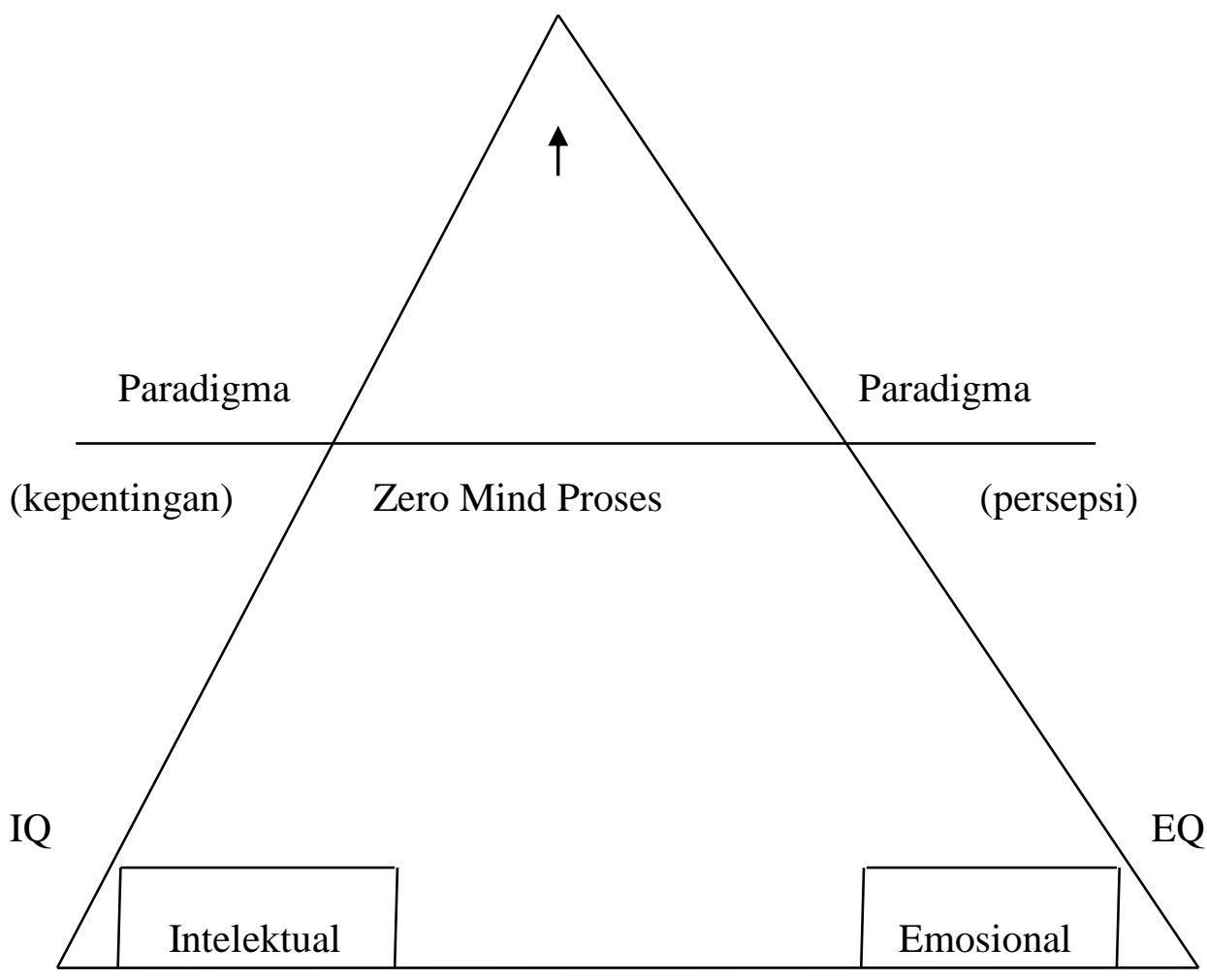

Dengan melihat hubungan yang di modelkan Ary Ginanjar Agustian (2008) di atas tampak bahwa segala sesuatunya tetap harus kembali pada sang pencipta, yaitu Tuhan. Bagaimanapun kita sebagai manusia mempunyai intelektual yang kuat,tanpa di kuatkan dengan emosi dan spiritual yang dimiliki maka hidup kita tetap berada pada tingkat yang sangat rendah. Karena kesemuanya itu, kita dapat dibedakan dengan hewan. Sehingga dikatakan bahwa kalau manusia tidak mempunyai sikap mental emosi dan spritual yang kuat, maka manusia dikategorikan sebagai hewan.

Dengan demikian, penerapan ESQ pada pendidikan dan pelatihan di setiap lembaga pendidikan dan pelatihan dapat diintregrasikan ke dalam semua 
komponen yang terkait di dalam lembaga pendidikan tersebut. Dalam rangka untuk mengubah karakter masyarakat bangsa yang mempunyai karakter berdasarkan ESQ ke depan.

\section{Implementasi Kurikulum Berbasis ESQ}

Pada dasarnya, penyempurnaan kurikulum berbasis kompetensi menjadi kurikulum tingkat satuan pendidikan (KTSP) sampai saat sekarang menjadi kurikulum 2013 suudah merupakan inovasi ideal yang di lakukan pemerintah. Namun, kurangnya SDM dan lemahnya kualifikasi guru mengakibatkan penjabaran KTSP masih belum optimal dan kurikulum masih dalam tahap sosialisasi. Masih banyak guru yang memegang filosofi sistem kurikulum lama yang memposisikan peserta didik sebagai objek, bukan sebagai subyek aktif pembelajaran. Seiring berubahnya kurikulum menjadi kurikulum 2013 ini, badan Litbang dan Diklat Kementerian Agama RI menyesuaikan dengan kurikulum 2013. Sehingga kurikulum yang di sesuaikan dengan kurikulum 2013 menjadi kurikulum berbasis ESQ, kurikulum ini di susun dalam bentuk mata diklat dan penambahan mata diklat yang terintegrasi.

Kurikulum diklat dengan jenis diklat sebelumnya yang di kembangkan pada balai diklat keagamaan yaitu:

1) Diklat Teknis fungsional pembentukan jabatan fungsional

2) Diklat teknis fungsional peningkatan kompetensi jabatan fungsional

3) Diklat teknis fungsional guru

4) Diklat teknis fungsional pengawas

5) Diklat teknis fungsional pranata laboratorium pendidikan

6) Diklat teknis fungsional widyaiswara

7) Diklat teknis fungsional penghulu

8) Diklat teknis fungsional penyuluh

9) Diklat teknis fungsional peneliti

10) Diklat teknis fungsional pustakawan

11) Diklat teknis fungsional lainnya 
12) Diklat teknis substansi pembekalan penugasan tambahan

13) Diklat teknis substansi penigkatan kompetensi

14) Diklat teknis substansi pemanfaatan lingkungan

15) Diklat teknis substansi Pembuatan dan penggunaan alat peraga

16) Diklat teknis substansi metodologi pembelajaran

17) Diklat teknis substansi evaluasi pembelajaran

18) Diklat teknis substansi pendalaman materi

19) Penyelenggaraan haji

20) Diklat teknis substansi kerukunan umat beragama

21) Diklat teknis substansi urusan agama Islam

22) Diklat teknis substansi urusan agama Katolik

23) Diklat teknis substansi urusan agama Hindu

24) Diklat teknis substansi urusan agama Budha

25) Diklat teknis substansi bimbingan masyarakat konghucu, dan

26) Diklat teknis substansi lainnya yang terkait dengan diklat teknis.

Dari keseluruhan diklat tersebut di atas, maka dapat di integrasikan pada mata diklat yang berbasis ESQ. Mata diklat tersebut adalah sebagai berikut:

1) Prinsip pembangunan karakter

2) Pengembangan SDM dan organisasi

3) Pembangunan sinergi kelompok

4) Disiplin pelaksanaan program

5) Membangun pribadi teladan

6) Budaya kerja

7) Kesadaran berbangsa dan bernegara

Dari ketujuh mata diklat ini di bangun berdasarkan konsep ESQ untuk membangun konsep ketuhanan pada diri masing-masing, terutama saat menjalankan tugas sesuai kompetensi masing-masing. Ketujuh mata diklat dan mata diklat substansi tersebut di kemas dengan mengintegrasikan konsep ESQ, dengan memberikan muatan-muatan yang emosional, 
spiritual yang berlandaskan empat pilar berbangsa dan bernegara pancasila, UUD 1945, NKRI, dan Bineka Tunggal Ika. Oleh karena itu, pendidikan dan pelatihan yang mengintegrasikan ESQ harus dilakukan secara berkelanjutan, sehingga dapat mengontrol seluruh aktivitas daripada output penyelenggaraan kediklatan. Alat untuk mengevaluasi mengontrol daripada output kediklatan pada badan litbang dan Diklat Kementerian Agama RI lebih khusus pada Balai Diklat Keagamaan Manado adalah melakukan monitoring dan evaluasi hasil diklat selama satu tahun berjalan, yang dilaksanakan setiap akhir tahun program kediklatan.

Sisitim monitoring dan evaluasi merupakan penilaian yang di terapkan adalah sistim penilaian berkelanjutan yang meliputi tiga aspek yaitu kognitif, psikomotorik, dan afektif serta penerapan konsep ESQ yang dilakukan pada setiap instansi masing-masing dengan mengedepankan sistim kerja mitra lintas sektoral.

Sistim evaluasi akhir yang berbasis kompetensi ESQ. Evaluasi hendaknya tidak sebatas ujian tertulis semata, akan tetapi, perilaku dan etika keseharian seharusnya menjadi tolak ukur lulus atau tidak lulusnya seorang peserta diklat. Untuk itu kompetensi daripada peserta diklat tidak ditekankan pada penilaian hasil jawaban diatas kertas saja, melainkan juga pada sikap peserta diklat selama proses pembelajaran selama mengikuti diklat seperti tingkat absensi di kelas, mental antimenyontek selama ujian, dan sikap moral spiritual lainnya.

Dalam konteks implementasi kurikulum ESQ pada Balai Diklat Keagamaan Manado, bagian yang paling penting berperan ialah seksi tenaga teknis. Hal ini dapat dilihat dalam struktur organisasi yang ada sebagaimana digambarkan berikut ini. 


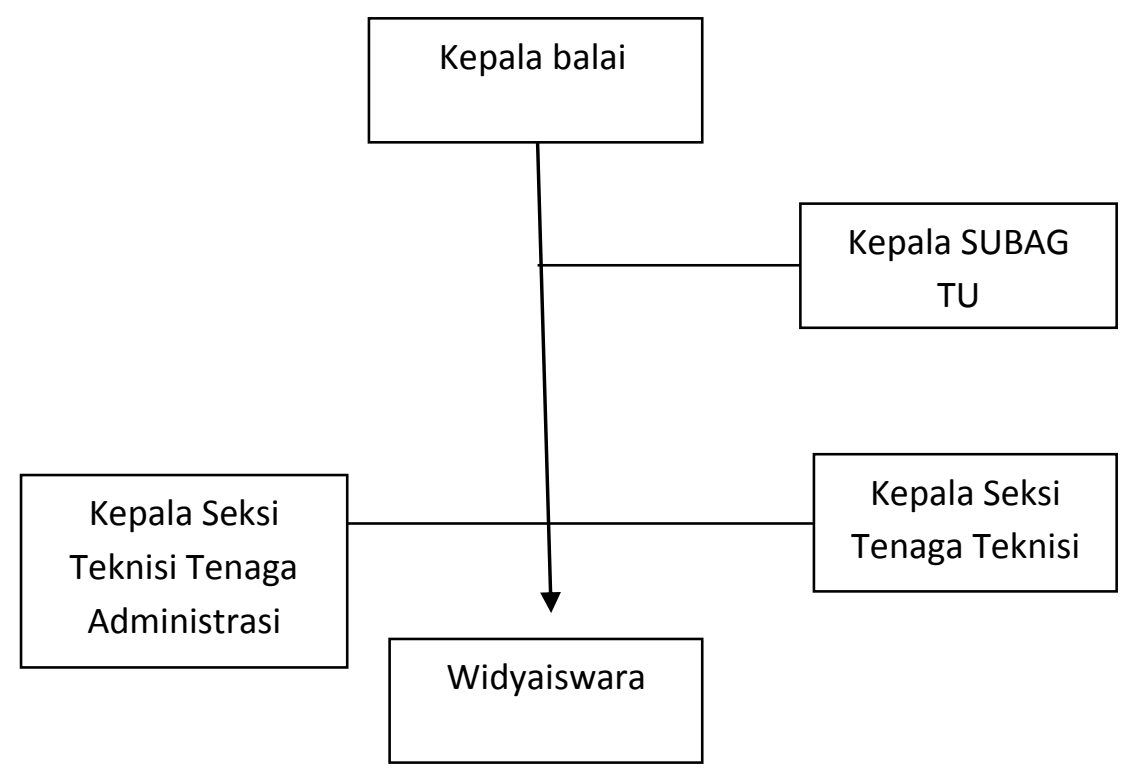

Selain itu, pengimplementasian kurikulum berbasis ESQ juga sangat berkaitan dengan visi dan misi yang di emban oleh Balai Diklat Keagamaan Manado. Dalam visinya, di nyatakan yaitu "terwjudnya aparatur keagamaan yang profesional dan berakhlak mulia. Sedangkan, misi yang di emban, yaitu:

a) Meningkatkan kualitas SDM penyelenggara Diklat

b) Meningkatkan kualitas manajemen kediklatan

c) Meningkatkan tata kelolah kepemerintahan yang bersih dan penguatan citra

d) Meningkatkan kualitas sarana dan prasarana diklat

e) Meningkatkan koordinasi dan kemitraan dengan instansi terkait

f) Meningkatkan ketersediaan data dan informasi kediklatan berbasis IT

g) Meningkatkan pelaksanaan monitoring dan evaluasi kediklatan

h) Meningkatkan pembinaan akhlak muliah aparatur kementerian agama

Dengan melihat struktur balai diklat keagamaan manado, seksi yang melakukan suatu perubahan kurikulum penyelenggaraan kediklatan adalah seksi tenaga teknis yang bertugas menyelenggarakan diklat teknis seperti diklat guru- 
guru, penghulu penyuluh agama dan diklat substansi lainnya, yang terintegrasi di dalam kurikulumnya pada nilai-nilai ESQ.

Visi dan misi yang disusun dan di laksanakan oleh Balai Diklat Keagamaan Manado yang bersinggungan dengan ESQ adalah meningkatkan pembinaan akhlak mulia aparatur kementerian agama, sehingga Balai Diklat Keagamaan Manado termotivasi untuk melakukan perubahan kurikulum yang mengintegrasikan mata diklat berdasarkan ESQ.

\section{Optimalisasi Nilai ESQ dalam Pendidikan dan Pelatihan}

Berdasarkan kajian sebelumnya bahwa bagaimana mengoptimalkan nilai-nilai ESQ pada lembaga diklat. Untuk mengoptimalkan ESQ pada pendidikan dan pelatihan adalah tentunya sebagai penyelenggaraan diklat harus menjadi panutan, karena seluruh karyawan Balai Diklat Keagamaan Manado dapat dijadikan sebagai model pengembangan konsep ESQ, dari seluruh pelanggan kediklatan khususnya diwilayah kerja Balai Diklat Keagamaan Manado.

Satu hal yang perlu di contoh adalah di Jepang, nilai-nilai moral spiritual tidaklah diajarkan dalam satu bentuk mata pelajaran khusus, akan tetapi diintegrasikan ke dalam semua materi ajar apapun, termasuk materi sains. Menariknya lagi, meski norma-norma masyarakat Jepang erat kaitannya dengan agama Shinto atau Budha, namun pelajaran agama tidak didapati di sekolah-sekolah formal Jepang. Nilainilai agama maupun moral diterapkan dalam perilaku sehari-hari di setiap jenjang pendidikan, terutama di pendidikan dasar. Sistem pendidikan seperti ini dikenal dengan sebutan doutokukyouiku.

Pendidikan tidak cukup jika diajarkan melalui kurikulum. Untuk menanamkan nilai-nilai luhur, pendidikan harus membentuk sebuah tradisi dan budaya yang kelak menjadi bibit-bibit peradaban. Kebiasaan itu bisa dimulai dari hal-hal sederhana seperti budaya membuang sampah pada tempatnya, budaya pergaulan, dan sebagainya seperti yang berlaku di Jepang. 
Optimalisasi nilai-nilai moral-spiritual (ESQ) ke dalam budaya edukatif sangat urgen untuk mengatasi ketimpangan antara kualitas kognisi dengan aspek nonkognisi yang selama ini masih berlaku dalam sistem pembelajaran di Indonesia. Pembentukan budaya tersebut tentu harus dilakukan secara bersamasama oleh semua unsur yang berada dalam komunitas edukatif, meliputi pendidik (guru, kepala sekolah, dosen, maupun tenaga pengajar lainnya), komite sekolah, peserta didik, dan staf/karyawan biasa, terutama di Kementerian Agama yang jika dilihat dari pembentukan karakter, di Kementerian Agama sebagai pusatnya.

Beberapa agenda awal yang dilakukan pada Balai Diklat Keagamaan Manado yang dibentuk sebagai sebuah budaya dalam komunitas edukatif sebagai lembaga kediklatan, diantaranya :

(1) Mengintegrasikan pendidikan ESQ ke semua materi/mata diklat termasuk pelajaran sains, sehingga tidak berpusat pada aspek kognitif saja. Misalnya, penanaman motivasi untuk melestarikan bumi atau hikmah penciptaan semesta melalui pelajaran Biologi.

(2) Perubahan paradigma 'Peserta diklat teladanl'. Jika selama ini pemilihan peserta diklat teladan berangkat pada penilaian cognitive-based competition semata, sudah saatnya paradigma itu dihapuskan. Peserta diklat teladan bukan saja peserta yang berprestasi dalam hal "rangking kelas" dan semisalnya, akan tetapi, peserta diklat yang berkarakter mandiri, taqwa, peka sosial, seharusnya mendapat apresiasi dan penilaian lebih.

(3) Pembenahan lingkungan belajar. Lingkungan yang sehat bukan saja memberikan stimulasi positif bagi proses transfer pengetahuan, tetapi juga memudahkan optimalisasi nilai-nilai luhur dalam lingkup pendidikan. Lingkungan sehat dapat dibentuk melalui budaya yang sehat pula.

(4) Mengembalikan fungsi fasilitas ibadah di lingkup akademik. Misalnya, memberikan ruang ibadah kepada peserta diklat baik peserta diklat yang beragama Islam, Kriten, Katolik, Budha, Hindu dan Konhucu. Ini dalam rangka untuk setiap mengerjakan sesuatu harus kita selalu mengingat 
kepada Tuhan sesibuk apapun kita. Seperti yng dilansir Marthen Luther bahwa kita banyak melakukan pekerjaan setiap hari tetapi kita harus menyisihkan waktu satu jam untuk berdoa.

Untuk menuntaskan masalah tersebut, Badan Litbang dan Diklat Kementerian Agama mencanangkan paradigma baru diklat untuk mencapaian siklus $4 \backslash$ (empat) tahun bagi yang berada di wilayah Indonesia Barat dan siklus 3 tahunan bagi yang berada di wilayah Indonesia Timur. Upaya tersebut dilakukan dalam bentuk diversifikasi model diklat yang terdiri dari penyelenggaraan (Diklat di Tempat Kerja (DDTK), penyelenggaraan Diklat Jarak Jauh (DJJ) dan Diklat Melalui Kelompokkelompok Kerja (MGMP, KKG, POKJAWAS, POKJAHULU), dan sebagainya. Kebijakan tersebut merupakan strategi cerdas yang membuka peluang besar untuk meningkatnya siklus diklat.

Masalah berikutnya adalah bagaimana model-model diklat tersebut dapat menarik para pegawai agar dapat mengikutinya. Hal ini menjadi penting, terutama berkaitan dengan model DJJ dan Diklat melalui Kelompok Kerja. Diklat ini lebih bersifat pilihan sehingga para pegawai tidak bisa dipaksa untuk mengikutinya. Agar para pegawai tertarik untuk mengikutinya maka kurikulum diklat harus benar-benar berisi kompetensi yang dibutuhkan oleh para pegawai. Dalam titik ini terjadi pertemuan antara kebijakan tentang Diversifikasi Diklat dengan TNA. Agar kegiatan DDTK dan DJJ ini dapat berjalan efektif dan efisien maka perlu persiapan yang matang sebagaimana yang seharusnya dilakukan pada setiap diklat yang dilaksanakan. Salah satu langkah penting adalah melaksanakan Analisis Kebutuhan Diklat (Training Need Assessment/TNA).

\section{Kesimpulan}

Berdasarkan pembahasan di atas, dapatlah disimpulkan sebagai berikut :

(1) Untuk meningkatkan sumber daya manusia pada Kementerian Agama khususnya pada Balai Diklat Keagamaan Manado, maka perlunya pendidikan dan pelatihan yang berbasis ESQ. ESQ ini dapat 
diintegrasikan pada kurikulum dan silabus pada program pendidikan dan pelatihan dari setiap penyelenggaraan diklat.

(2) Program diklat jika berada pada taraf kognitif saja, maka penyelenggaraan diklat hanya bernuansa kepentingan IQ saja. Dengan adanya pemanfaatan dalam kurikulum dan mata diklat yang terintegrasi pada EQ dan SQ, dan dapat dilanjutkan dengan ESQ, untuk ke depan akan mendapatkan sumber daya manusia yang siap pakai baik secara IQ, EQ dan SQ untuk ke depan akan mendapatkan sumber daya manusia yang siap pakai baik secara IQ, EQ, dan SQ untuk menjemput masa depan bangsa, yang berakhlak mulai, baik pada peserta diklat itu sendiri maupun pada siswa-siswanya atau pelangganpelanggan kediklatan.

(3) ESQ merupakan suatu model yang dilakukan oleh Bada Litbang dan Diklat Kementerian Agama, untuk kepentingan birokrasi pemerintahan khususnya tugas pemerintah di bidang agama dan keagamaan. ESQ adalah proses yang dilakukan secara berkelanjutan untuk meningkatkan kinerja para pegawai Kementerian Agama secara keseluruhan.

Berdasarkan pembahasan dan kesimpulan, maka beberapa hal dapat dikemukakan sebagai rekomendasi, yaitu :

(1) Kepala Pusdiklat Badan Litbang dan Diklat Kementerian Agama RI, diharapkan dalam mengembangkan kurikulum harus bersesuaian dengan kurikulum yang dikembaangkan oleh Kementerian Pendidikan dan Kebudayaan.

(2) Kepada Kepala Balai Diklat Keagamaan Manado, agar anggaran pelaksanaan penyelenggaraan diklat berbasis ESQ ditingkatkan. 


\section{Daftar Pustaka}

Agustian A.G. 2008. Rahasia Sukses Membangkitkan ESQ Power. Jakarta: Arga

Ali. M. dkk. 2007. Ilmu dan Aplikasi Pendidikan. Bandung: Pedagagiana Press

Atmodiwirio, S. 2002. Manajemen Pelatihan, Jakarta: Ardalizya Jaya

Borba, M. 2008. Membangun Kecerdasan Moral. Jakarta: PT Gramedia Pustaka Utama.

Chatib,M. 2012. Sekolahnya Manusia. Bandung: PT. Mizan Pustaka.

Haris. Ramli. 2004. Teknik Analisis Kebutuhan Diklat. Jakarta: Pusdiklat Tenaga Teknis Keagamaan Departemen Agama

Given. B. K. 2007. Brain-Based Teaching. Bandung: PT Mizan Pustaka

Goleman, D. 2002. Emotional Intelligence (Kecerdasan Emosional) Jakarta: Gramedia

Kennedy, C. 1987. Innovation for Change, Teacher Development and Innovation. ELT Journal 41/3

Lembaga Administrasi Negara RI. 2005. Teknik AKD 1. Jakarta: LAN

Lembaga Administrasi Negara RI. 2005. Teknik AKD 2. Jakarta: LAN

Mahayani, D. 1999. Menjemput Masa Depan. PT. Bandung: Remaja Rosdakarya.

Nggermanto, A. 2002. Quantum Quotient, ( Kecerdasan Quantum). Bandung: Nuansa

Pasiak, T. 2007. Braim Management for Self Improvement. Bandung: Mizan

Pasiak,T. 2003. Revolusi IQ/EQ/SQ Antara Neurosains dan Al-Qur'an.Bandung: Mizan 
Ridley, Matt. 2003. Nature via Nature, Genes, Experience an what makes us human. London: Fourth Estate

Roesma, Sonja. 2009. Kepemimpinan Berdasarkan Golongan Darah. Jakarta: Rajut Publishing

Stein S. J.\& Book H.E. 2003. Ledakan EQ 15 Prinsip Dasar Kecerdasan Emosional Meraih Sukses (Terjemahan), Bandung: Kaifa

Suraji. T. Th. Manajemen Diklat. Jakarta: Sekolah Tinggi Ilmu Administrasi Negara Repoblik Indonesia.

Wibowo. 2011. Manajement Perubahan. Jakarta: Raja Grafindo Persada

Wijaya. Cece. Djaja Jajuri, dan A. Tabrani Rusyam. 1991. Upaya Pembaharuan dalam Bidang Pendidikan dan Pengajaran. Bandung: Penerbit PT. Remaja Rosdakarya. 